\title{
The Economic Contribution of the Resources Sector by Regional Areas in Queensland
}

\author{
John Rolfe*, Daniel Gregg and Galina Ivanova \\ Centre for Environmntal Management \\ Central Queensland University \\ North Rockhampton QLD Australia 4702 \\ (Email:j.rolfe@cqu.edu.au) \\ Reuben Lawrence \\ Lawrence Consulting \\ PO Box 2567 \\ Toowoomba QLD Australia 4350 \\ (Email: reuben@lawrenceconsulting.com.au) \\ and \\ David Rynne \\ Queensland Resources Council \\ Level 13, 133 Mary Street \\ Brisbane, QLD 4000, Australia \\ (Email:davidr@qrc.org.au)
}

Abstract: Although it is widely accepted that the resources sector makes a significant contribution to national and state economies, information about how it impacts on local and regional economies is much scarcer. Understanding the spread of economic stimulus and subsequent indirect business and consumption effects is important because of the changing patterns of business operations, employment and supply chains in the resources sector. The focus of the research reported in this paper was to identify the geographical spread of economic impacts from the resources sector across Queensland. The results of the analysis demonstrate that incomes and expenditures from the resources sectors are widely distributed across the state, and generate significant flow-on effects. It is notable that the industry makes a strong direct contribution in many of the more remote areas of Queensland, helping to underpin economic conditions in those regions. Expenditure from the resources industry has indirect impacts on the business environment in many areas, and generates substantial levels of production in south-east Queensland and central Queensland in particular.

* Corresponding author. 


\section{INTRODUCTION}

The resources sector, encompassing mining, gas, energy and minerals processing industries, makes a major contribution to the Australian economy, particularly through the key resource states of Western Australia and Queensland (Garton 2008, Lim et al.2009). However, information about how it impacts on local and regional economies is much scarcer, particularly when changes over time are considered. Changes in operations management, workforce location and supply purchasing mean that the direct economic impacts of resource operations are no longer focused on local communities in the same way that they were thirty years ago (Rolfe et al. 2007). From the 1990s, many mining companies reduced their provision of housing in mining towns and responsibility for employees outside of work hours, introduced greater use of business suppliers and contractors, particularly for non-core operations, and changed a number of work patterns, including moves towards longer shift patterns (Rolfe et al. 2007, Zheng et al. 2007).

These changes have had the effect of diffusing the impact of direct mining expenditures in two main ways. First, greater reliance on external suppliers and contractors has led to increased development of business supply chains, which are often located in regional hubs and major centres (Rolfe et al. 2007). Second, increased flexibility about workforce location and increased use of drive-in/drive-out and fly-in/fly-out workforces means that many mining salaries flow to areas outside of direct mining activity. These trends in workforce mobility are underpinned by improved transportation and social and demographic changes. Factors such as employment for partners and children, access to education, health and recreation services, and convenience and lifestyle issues are making it more attractive for mining employees and their families to live in larger centres or coastal towns.

The focus of the research reported in this paper was to identify the geographical spread of economic impacts from the resources sector across Queensland. Impacts of resource industries on regional and metropolitan areas of Queensland occur through direct, indirect and final consumption effects. There are two key types of direct impacts:

- Wages for direct employment of workforce

- Expenditure on business services in local and regional economies

Business expenditure generates both upstream and downstream ripple effects through the business supply chain as local businesses purchase goods and services from other businesses, often through several links in the supply chain. The net effect of subsequent rounds of economic activity in the business supply chain can be categorised as indirect effects. The increased employment that is generated through the direct effects (resources sector employment) and the indirect effects (business supply chain) generates a number of final consumption effects to support the increased population base.

The contribution of this study is that it identifies the extent to which direct, indirect and final consumption impacts are located in local and regional areas in Queensland, and the extent to which those impacts are transmitted to other areas of the state. The research has been conducted with the involvement of the resources industry through the Queensland Resources Council, which collated expenditure data across the state. 
The remainder of the paper is structured as follows. An overview of the resources sector in Queensland is provided in the next section, followed in section three by a review of the inputoutput methodology used in this study, together with a summary of previous literature. Data collection and analysis for the study is reported in section four, and the modelling results at the state, regional and local government levels reported in the following three sections. Final conclusions are reported in section eight.

\section{OVERVIEW OF THE RESOURCES INDUSTRY IN QUEENSLAND}

The resources sector in Queensland involves the extraction and processing of a wide variety of resources as well as some electricity generation from these resources.

Activity and growth in resources activities is concentrated in some regional areas (LGAQ 2010), including:

- The Darling Downs Statistical Division (SD) currently has a number of gas and coal-fired electricity generation plants, gas and (thermal) coal production, and is experiencing major growth in the production of coal seam gas (CSG) as an input for liquefied natural gas (LNG) processing;

- The South West SD currently has gas-fired electricity generation, produces processed natural gas, liquefied petroleum gas and natural gas, and is also experiencing major growth in the production of CSG as an input for LNG processing;

- The Mackay and Fitzroy SDs are the lead regions for producing metallurgical and thermal coal, gas and coal fired electricity generation, limestone and cement related production, magnesite and magnesia, alumina and aluminium. These SDs also have the major coal export port facilities;

- The Northern and North-West SDs are largely involved in producing base metals, particularly gold, silver, nickel, copper, lead and zinc;

- The Far North SD has bauxite production at Weipa, and some additional production of tin and gold.

The resources sector has been on a very strong growth trajectory since about 2003, when high overseas growth, especially in developing countries like China and India, pushed up demand for minerals and energy commodities. The growth has led to increases in employment and regional incomes, with an increase in direct mining employment in Queensland from 18,300 employees in 2002/03 to 42,500 employees in 2009-10 (Figure 1). Additional employees will also be involved in other non-mining industries of the resources sector. The resources industry typically has much higher salary levels than many other industry sectors. For example, May 2010 ABS data reveals that the mining industry in Australia paid 2.1 times more per employee than the retail trade industry, and 1.8 times more per employee in the manufacturing industry ${ }^{1}$. Higher levels of employment and income provide a base for larger inputs into regional and metropolitan economies. 
Figure 1: Employment in the Queensland Mining Sector Over Time

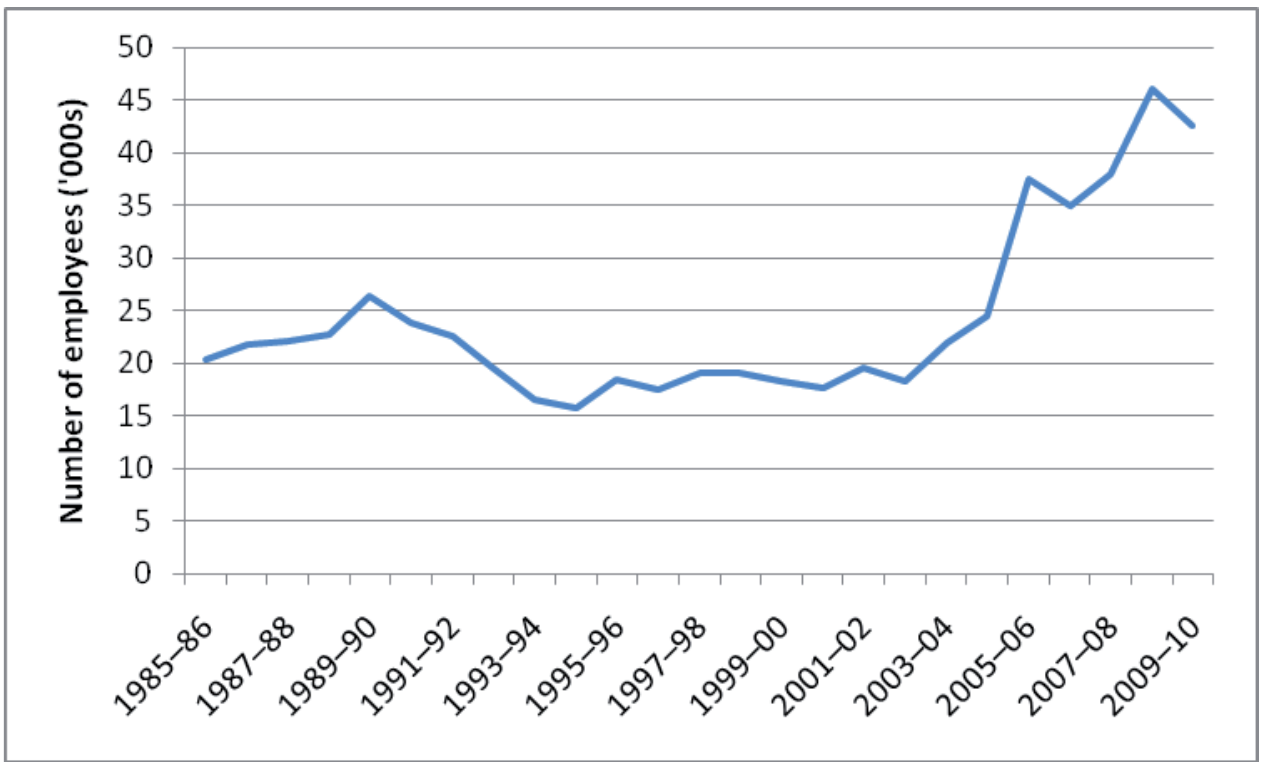

Source: OESR, ABS Labour force data, Cat: 6291.0.55.003

Increased activity in the resources sector generates direct impacts on regional and metropolitan areas of Queensland and Australian economies in five key ways:

- The expenditure of companies on contractor and employee wages and salaries for extraction, development and exploration activities,

- The expenditure of companies on contractors and suppliers associated with extraction, development and exploration activities,

- The voluntary expenditure of companies on community infrastructure such as health centres,

- Increased dividends to investors in resources firms which are then used for the purchases of goods and services,

- Increased royalty payments and tax revenues to all levels of government.

Those direct impacts generate a number of indirect and consumption impacts, principally through:

- The flow-on effects of business expenditure back into other sectors of the economy,

- The flow-on effects of consumption expenditure back into other sectors of the economy, and

- The expenditure of government on infrastructure, goods and services. 


\section{METHODOLOGY}

\subsection{Input-Output Modelling}

For this study, Input-Output (I-O) modelling has been used to estimate the sum of direct, indirect and final consumption of the resources industry on different regions of Queensland. I-O techniques provide a solid approach for taking account of the inter-relationships between the various sectors of the economy in the short-term and hence are an appropriate tool for determining the direct, indirect and induced economic impact of economic stimuli. An inputoutput model can be used to identify how different sectors in the economy interact, and how changes in one sector generate 'ripple' effects through the wider economy in terms of changes in income, expenditure and employment (Jensen and West 2002, Loveridge 2004). I-O models can be used to capture only the indirect impacts that occur through other industry sectors (Type I models), or the indirect plus the final consumption effects (Type II models).

The I-O technique was developed by Wassily Leontief in the 1930s to describe how impacts in one sector of an economy interacted with other sectors to generate economic changes, with matrix algebra used to perform the complex calculations. More advanced forms of I-O models are computable general equilibrium models, which are used for analysis of larger national economies. However the standard I-O model approach remains particularly useful for predicting the impacts of events or projects in an economy, or analysing regional level economies (Loveridge 2004). In this case study the I-O models were based on the ABS models of the Australian and Queensland economy generated from general equilibrium models.

A concept underlying I-O modelling is that an initial economic shock or stimulus can have multiplier effects through a series of successive spending rounds. The size of the economic multiplier in a local or regional area can be summarised in the following way. The key concepts of interest (Jensen and West 2002) are:

- The extent to which project operators purchase inputs from the local or regional economy. Examples of inputs include wages for labour supplied from the local or regional area, and purchases of goods and services. The more that a project operator sources from the local or regional economy, the more money that is directly injected into the economy.

- The extent to which money spent in a local or regional economy is retained within that economy. If there is not much opportunity for people receiving income to spend it on goods and services in their local or regional area, then not as much money will be kept in the local or regional area. Larger and more diverse regional economies tend to be better at keeping expenditures in their economy and not 'losing' it to other regions.

To generate predictions, the economic contribution of an industry is applied to the relevant industry sectors of the input-output model of a regional economy. The stimulus from economic activity can be traced through the economy in several different ways:

- The first round effects, or direct effects, are those from the expenditure in purchasing goods and services from other industries; 
- The second round effects are those from the supplying industries increasing their purchases to meet the additional demand. The second and subsequent rounds of purchasing are termed the indirect effects; and

- The consumption-induced effects identify the increase in economic activity generated to service the additional employment (and population) created through the direct and indirect effects.

Predictions from I-O models are summarised in terms of multipliers and changes in four key variables:

\section{Output}

The output impact measures the increase in gross sales throughout the whole economy by summing all the individual transactions resulting, directly and indirectly, from the economic stimulus.

\section{Income}

The income impact measures the additional amount of wages and salaries paid to employees of the industry under consideration and to other industries benefiting from the stimulus to the economy.

\section{Employment}

The employment impact measures the number of jobs created by the stimulus, both directly and indirectly.

\section{Value Added}

The value added or Gross Regional Product (GRP) impact measures only the net activity at each stage of production. GRP is defined as the addition of consumption, investment and government expenditure, plus exports of goods and services, minus imports of goods and services for a region. The GRP impacts are the preferred measure for the assessment and contribution of a stimulus to the economy.

Key advantages of using input-output models are the fineness of detail available at a disaggregated industry level, the relative ease of application, particularly for sub-regional levels, and the ability to model effects in a timely manner (Loveridge 2004). However, care has to be taken in its application and interpretation of results. Key assumptions that underpin the application of I-O models are (Stilwell et al. 2000, Department of Mines and Energy 2007):

- Constant prices

- Fixed technology

- Fixed import shares

- Constant labour productivity within sectors

- No constraints on supplies of factor inputs

Type II models involve additional assumptions about fixed relationships between income and consumption patterns. A further issue is that both Type I and Type II models do not account for all forms of potential efficiency interactions between industries with changes. These factors mean that the results of I-O models should generally be treated as the upper bound 
of estimates, and that care has to be taken in interpreting the results of very large changes in demand or production.

\subsection{Previous Literature}

There have been several studies applying input-output modelling techniques to analyse the contribution of resources industries to economic growth in different countries and regions. Rubin and Solomon (1983) used economic base and regional multiplier analysis to estimate the impacts of coal liquification projects on 27 counties in Indiana and Kentucky in the United States. Their analysis identified an economic base multiplier of 7.93, implying that for every dollar of new income generated by the projects in the region, an additional $\$ 6.93$ of additional new income would be generated through the remainder of the region.

Stilwell et al. (2000) used the technique to estimate the contribution of the mining industry to South Africa over a 22 year period. They found that while the employment multipliers were tending to rise over time, they were not substantially different from other sectors in the South African economy. Employment multipliers were estimated to range between 22.85 and 33.69 for different types of mining activities.

Aroca (2001) estimated that for each US dollar produced by mining industry in Chile, $9 \%$ is spent on compensation of employees in mining sector, and $7-15 \%$ is spend on compensation of employees in other sectors. The open model multipliers (not including effects on final consumption from additional households) ranged from 1.01 to 1.65. That means that each additional dollar that is spent on final demand will increase the total output by US\$1.01 to US\$1.65 depending on the industry the initial dollar is spent. If the final consumption effects were included (closed model), the size of multiplier in the mining sector was estimated at 1.8. Aroca (2001) estimated that an additional employee in the private mining firm means that 3.1 (open model) or 5.7 (closed model) additional workers will be hired in the regional economy.

Bangsund and Leistritz (2007) estimated the economic contribution of the petroleum industry to the state economy of North Dakota in the United States. The total economic impacts were summarised in terms of direct and indirect business impacts, direct and indirect employment impacts, and additions to government revenues. The direct expenditure on businesses were estimated at US\$1.5B, with every dollar spent generating a further 63 cents in indirect activity, generating total business activity of US\$2.4B. Direct employment was estimated at 5,267 jobs, and additional employment through the business supply chain was estimated at 20,650 fulltime jobs. Total personal income was estimated at US\$1.5B, and there were direct and indirect contributions to local and state government tax revenues of US\$280M and US\$55M respectively.

Fannin et al. (2008) used community impact models to estimate the economic effects of oil and gas production from deepwater leases on growth on a regional area of Louisiana in the United States. They estimated that the industry was creating 0.59 indirect (business sector) jobs in the Lafourche Parish economy for every one direct job, with largest impacts in the transport and warehousing industry.

Leaming (2010) estimated the economic impacts fro the copper industry to the Arizona economy in 2009. He estimated that $25 \%$ (or $\$ 767$ million) of US\$3 billion direct payments to Arizona residents, business firms, and governments, were paid as personal income. The 
largest share of spending (70\% or US $\$ 2.1$ billion) was on purchases from other firms within Arizona, while the payments for state and local governments reached \$151 million, The estimated indirect economic impacts was more than two times higher than the direct impacts.

Previous modelling directly relevant to this study was carried out by ACIL Tasman in 2007, and reported by the State of Queensland (Department of Mines and Energy 2007). In that report, the contribution of the mining and minerals processing sector to the Queensland economy, using 2004-05 data, was estimated with the use of I-O analysis and general equilibrium modelling. The results of that study identified that in 2004-05, Queensland's mineral and mineral processing industry generated a direct value-added contribution of $\$ 15,377$ million, or $9.7 \%$ of Gross State Product. These two industries also were estimated to generate direct employment of 50,007 people, with total employment effects, including both direct and indirect effects, estimated at 216,041 people. Total income, including both direct and indirect salaries and wages, was estimated at $\$ 11,122$ million. These estimates represented large changes on analysis of 1999-00 data, demonstrating significant growth in the industry.

\section{DATA COLLECTION AND ANALYSIS}

This study is different from the ACIL Tasman 2004-05 study because it applies a sample (estimated to be $95 \%$ of the Queensland resources sector) of primary spend data from the resource companies to accurately calculate the direct and indirect economic impacts (value add and employment in the main) at the Local Government Area (LGA) level, instead of estimating impacts from total revenue injected. As well, the resource sector used in this study is slightly more encompassing than the mining and mineral processing sector used in the ACIL-Tasman study.

The approach adopted in this study captures the level of spending injection into the economy from both current operations and new investment, in comparison to more standard approaches which only capture the impacts of current operations. As well, the methodology adopted in this study allows more accurate assessment of economic impacts at the LGA level, which are not available through general equilibrium modelling. Further details on the methodology and analysis applied are available from Rolfe et al. (2010).

\subsection{Data Collection and Sources}

Operational expenditure data for current resource projects and capital expenditure data from proposed investments currently under development was provided by resources companies in Queensland through the QRC (Table 1). Companies were asked to provide data of expenditure in Queensland for the 2009-2010 year. Approximately 95 per cent of the resources sector (by value of production) provided their data to the QRC for this project. Companies supplied data on expenditure by three key categories: salaries, voluntary community contributions and business supplies ${ }^{2}$. The expenditure was identified by the postcode where the salary was paid (residence of the worker or contractor) and where the community contributions and business expenditures were paid, thus providing a trace about the location of relevant salary earners and

2 The latter two were aggregated as their economic effects are identical 
business operators ${ }^{3}$. Geography correspondence files ${ }^{4}$ from the Australian Bureau of Statistics were employed to group the salary and expenditure data by postcode to 74 Local Government Areas and 13 Statistical Divisions in Queensland. This then provided the basic input data for analysis. A total of $\$ 25$ billion in annual spend data by postcode was identified.

\subsection{Construction of the Regional Input-Output Models}

For the derivation of the regional I-O tables for the Statistical Divisions (SDs) and Local Government Areas (LGAs) in Queensland, a variable interference non-survey technique was applied, involving a formalized non-survey method compilation. This allowed data on direct effects of the resources industry to be inserted at any stage of the compilation procedure. This approach is based primarily on a mechanical procedure (mainly on cross-industry location quotients) for the regionalisation of the national direct requirements matrix (DRM), which is at the core of any I-O table.

Table 1: Companies Supplying Data for the Project.

\begin{tabular}{|l|l|}
\hline Anglo American Metallurgical Coal & Origin Energy Australia \\
\hline Arrow Energy Limited & Peabody Energy Australia Pty Ltd \\
\hline Bowen Basin Coal Management Pty & QER Pty Ltd \\
\hline BHP Cannington & QGC Limited \\
\hline Queensland Alumina Limited & Queensland Magnesia Pty Ltd \\
\hline BHP Billiton Mitsubishi Alliance (BMA) & Queensland Nickel Pty Ltd \\
\hline Caledon Resources PLC & Rio Tinto Coal Australia \\
\hline Cement Australia & Rio Tinto Alcan \\
\hline Citigold Corporation Limited & Santos/TOGA Pty Ltd \\
\hline Ensham Resources Pty Ltd & Sonoma Mine Management Pty Ltd \\
\hline ERM Power Pty Ltd & Stanwell Power Corporation \\
\hline Hancock Coal Pty Ltd & Tarong Energy Corporation \\
\hline Millmerran Power Management Pty Ltd & Consolidated Rutile Limited \\
\hline Ivanhoe Australia Limited & Vale Australia \\
\hline Jellinbah Group & Wesfarmers Resources \\
\hline Macarthur Coal Limited & Xstrata Coal Australia Pty Ltd \\
\hline MetroCoal Limited & Xstrata Mount Isa Mines Ltd \\
\hline Minerals and Metals Group Limited & Xstrata Ernest Henry Mining Pty Ltd \\
\hline New Hope Coal Australia Ltd & Xstrata Zinc \\
\hline North Queensland Metals Ltd & Yancoal Australia \\
\hline
\end{tabular}

3 It was not possible to identify imports specifically out of the spending patterns. Some expenditure in the Brisbane CBD in particular may have transferred to imports.

4 http://www.abs.gov.au/AUSSTATS/abs@.nsf/Lookup/1259.0.30.001Main+Features 1July\%202010? OpenDocument 
In summary, the construction of the local and regional I-O models employed the following steps:

- Adjustment to the latest available national I-O table

- Computation of the regional direct requirement matrix

- Aggregation of regional sectors (if necessary)

- Computation of the complete regional I-O table

All the necessary data for the regionalization procedure were collected from the Australian Bureau of Statistics as well as other reliable sources for secondary data such as regional household expenditure patterns, income and productivity measures. The latest available national I-O tables was 2005-06, which consisted of 109 sectors of economic activity, at the 4-digit level, compiled following the industry-technology assumption, product-by-product, with total flows and valued at basic values in current prices.

For estimating the regional I-O tables, and especially in the interpretation of results, relevant limitations of the I-O approach (static, linear production function, no substitution or scale economy effects, infinite elasticity of supply) were taken into consideration. Once the I-O models were generated, predictions of impact were estimated for each regional area of interest in Queensland using the available data on salary and business expenditure. These data on direct expenditures were inputted into the models to generate estimates of changes in outcome, incomes, employment and value added.

The predictions of the I-O models for each SD and LGA were estimated in two streams (Figure 2). The first involved the economic impacts of expenditure on business goods and

Figure 2: Simplified Structure of Predictions from I-O Models.

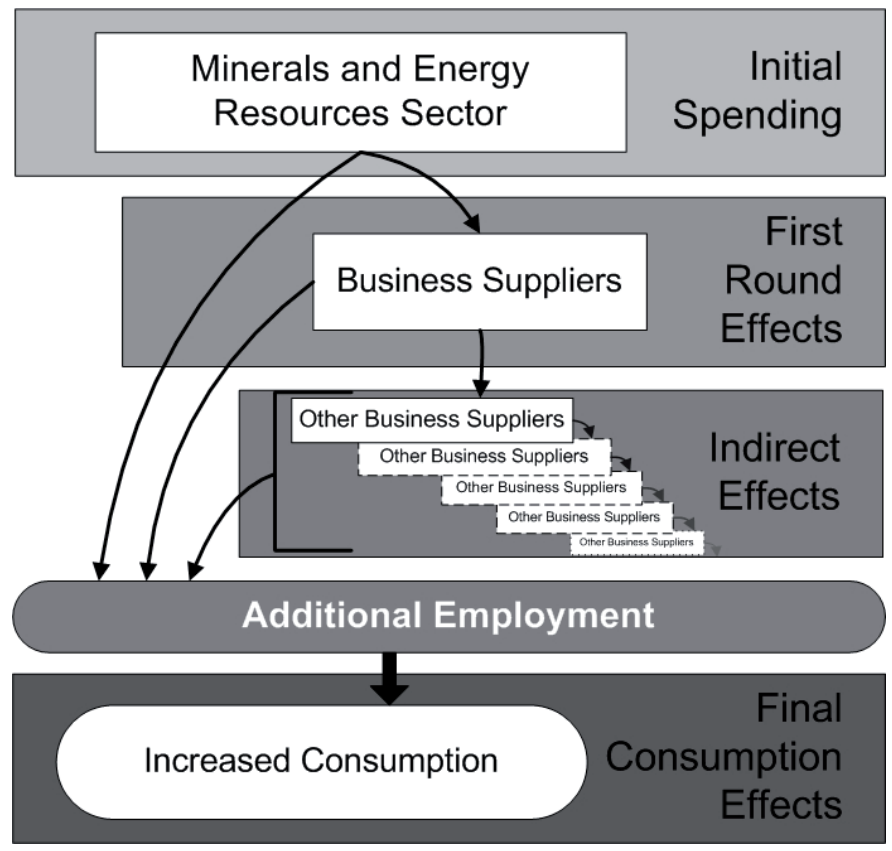


services (business suppliers), while the second involved economic expenditure on the labour force. The outputs of the models can be classified into First Round and Indirect Effects, representing industry impacts through the business chain, and Final Consumption effects, which represent the economic activity needed to support the increased workforce from Direct, First Round and Indirect Effects.

The data collection and the methodology applied in this study are notable in three key aspects.

- First, the data collected on actual spending by the resources industry allowed an assessment of impacts by spending in the economy in comparison to the more traditional approach of predicting economic impacts from total revenue changes.

- Second, the collection of primary data by local area allowed a much more accurate assessment of the direct impacts by geographic area than had previously been available.

- Third, the application of the I-O modelling framework down to the LGA level, when combined with the accuracy of the primary data, meant that relatively accurate models of local impacts from the resources sector could be generated.

The outcomes of the data collection and modelling approach meant that the assessment of direct, indirect and consumption effects could be expected to be more detailed and accurate at the LGA level than could be achieved with standard applications of general equilibrium models.

\section{BENEFITS TO QUEENSLAND}

\subsection{Direct Effects}

The data generated in this project (Table 2) indicated that the Queensland resources sector had paid more than $\$ 4.95$ billion in wages and salaries in 2009-10 year. The total number of employees and contractors identified through the data collection were 38,034 persons, indicating that the average salary level across the resources sector is $\$ 134,230$ per annum.

The sum of purchases from suppliers and voluntary community contributions in Queensland amounted to about $\$ 17.4$ billion in 2009-10. Another $\$ 2.8$ billion was spent on suppliers from outside of Queensland. Australia wide, the sum of all three spends in 2009-10 came to in excess of $\$ 25$ billion.

The bulk of direct expenditure on suppliers is going to the Brisbane region ${ }^{5}(59 \%)$, followed by the Mackay region (14\%), the Fitzroy region (13\%), and North-West (5\%). In contrast, the value of production data shows that outputs are largely generated in the Mackay region (43\%), the Fitzroy region (28\%), the North-West region (16.5\%), and the Northern region $(4.4 \%)$. The distribution of aggregate royalty payments shows that $59.9 \%$ of royalties are being generated from the Mackay region, 24.9\% from the Fitzroy region, and 5.8\% from the North-West region. The breakup of royalties by commodity type shows that about $88 \%$ of royalty payments across the state are generated by coal production.

5 It is possible that some of the expenditure identified for Brisbane was transferring through to imports. 
Table 2: Summary Data from Resources Sector used in Analysis

\begin{tabular}{|c|c|c|c|c|c|c|}
\hline $\begin{array}{l}\text { Statistical Division } \\
\text { (SD) }\end{array}$ & $\begin{array}{l}\text { Residing } \\
\text { employees } \\
\text { and } \\
\text { contractors }\end{array}$ & $\begin{array}{l}\text { Salaries } \\
\text { spend }\end{array}$ & $\begin{array}{c}\text { Business } \\
\text { supplier \& } \\
\text { community } \\
\text { spend }\end{array}$ & $\begin{array}{l}\text { Total Direct } \\
\text { Economic } \\
\text { stimulus }\end{array}$ & $\begin{array}{l}\text { Aggregate } \\
\text { value of } \\
\text { production } \\
\text { of current } \\
\text { resource } \\
\text { projects }\end{array}$ & $\begin{array}{r}\text { Aggregate } \\
\text { royalties } \\
\text { generated }\end{array}$ \\
\hline & & $\$ M$ & $\$ M$ & $\$ M$ & $\$ M$ & $\$ M$ \\
\hline Brisbane & 6,940 & 903.8 & $9,479.0$ & $10,382.8$ & 266.1 & 14.0 \\
\hline Central West & 77 & 10.0 & 25.3 & 35.2 & 429.0 & 33.0 \\
\hline Darling Downs & 1,185 & 154.3 & 430.4 & 584.7 & $1,596.5$ & 88.6 \\
\hline Far North & 1,485 & 193.4 & 114.3 & 307.7 & 544.4 & 17.6 \\
\hline Fitzroy & 9,627 & $1,253.7$ & $2,406.7$ & $3,660.4$ & $10,836.0$ & 522.4 \\
\hline Gold Coast & 218 & 28.4 & 113.3 & 141.7 & 0.0 & 0.0 \\
\hline Mackay & 10,322 & $1,344.3$ & $2,678.8$ & $4,023.0$ & $16,706.9$ & $1,254.8$ \\
\hline North West & 3,979 & 518.2 & 927.8 & $1,446.0$ & $4,784.7$ & 111.1 \\
\hline Northern & 2,659 & 346.3 & 654.7 & $1,001.0$ & 748.6 & 20.2 \\
\hline South West & 301 & 39.2 & 139.5 & 178.6 & 609.6 & 60.4 \\
\hline Sunshine Coast & 377 & 49.1 & 157.5 & 206.6 & 0.0 & 0.0 \\
\hline West Moreton & 183 & 23.9 & 16.1 & 40.0 & 2.3 & 0.0 \\
\hline Wide Bay-Burnett & 677 & 88.1 & 213.5 & 301.6 & 0.0 & 0.0 \\
\hline Total Queensland & 38,031 & $4,952.7$ & $17,356.7$ & $22,309.5$ & $36,524.1$ & $2,122.2$ \\
\hline
\end{tabular}

\subsection{Indirect and Final Consumption Effects}

The I-O modelling conducted for this project has estimated the indirect and consumption effects flowing from the business expenditure of $\$ 17.11$ billion, and the employment expenditure of $\$ 4.95$ billion. These impacts have been first modelled to identify the level of impacts on output, incomes, employment and industry value added in Queensland (Table 3).

The results of the I-O modelling, together with other data drawn from the QRC and the Australian Bureau of Statistics, allow predictions to be made about the total size of impacts from the resources sector on the economy. For each key measure, the total impact on the economy is the sum of the direct effects from industry, the indirect effects through the business chain, and the final consumption effects. While the I-O models have estimated the indirect and consumption effects, other primary data is needed to estimate the direct effects. Information about the direct Output, Income and Employment effects are already available from the QRC data, and have been incorporated into Table 3 to estimate total effects for Queensland and Australia.

When both (and only) the business supply and employment effects are considered, the resources sector is generating approximately $\$ 50.1$ billion in Gross State Product ( $\$ 22.1$ billion in direct effects, and $\$ 28.1$ billion in value added effects), and is responsible for generating approximately 292,000 jobs (38,093 in directemployment and 254,000 in additional employment).

The results of the current study compared to similar work reported by QDME (2007) on 1999-00 and 2004-05 data demonstrates that the resources sector continues to grow its share of the Queensland economy (Table 4). The industry definition varies slightly between studies, 


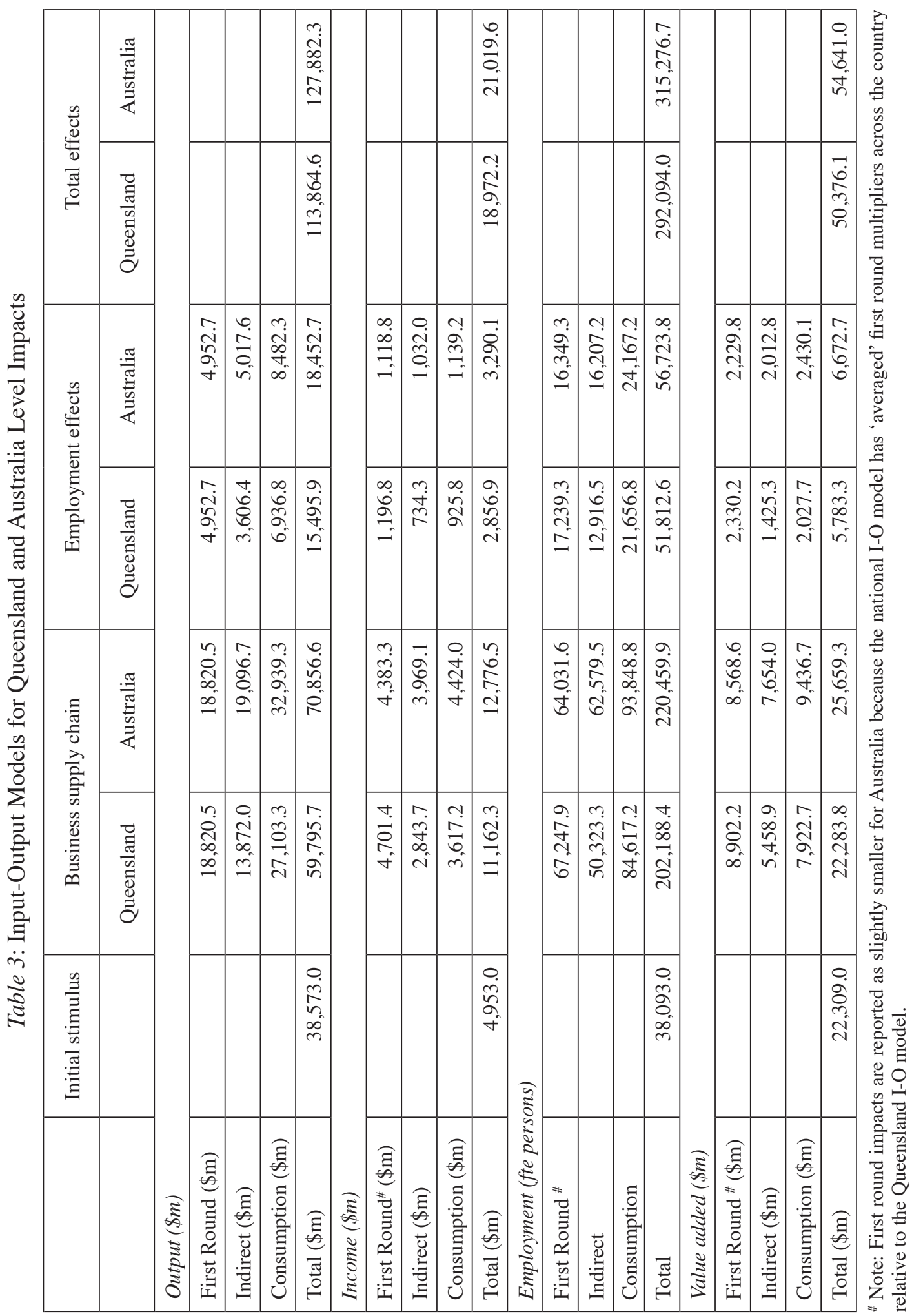


with the previous modelling by ACIL Tasman focusing on mining and mineral processing sectors only compared to the full resources sector covered in the current study.

\section{BENEFITS BY STATISTICAL DIVISIONS}

Queensland resources sector expenditures, split across salary and supplier and voluntary community contribution expenditure, varied considerably across SDs. The level of employment, and direct expenditure on employees, including direct employees and contractors, as well as expenditure on business supplies, is summarised for the 13 SDs in Queensland in Table 5. Information is also included about estimated levels of total employment and Gross Regional Product for comparative purposes.

The data identify that a significant amount of primary spend occurs in Brisbane. For this analysis, expenditure on contract employment has been reallocated across the state to reflect the geographic dispersion of this group of workers. All other expenditure to Queensland postcodes has been treated as occurring in the state, with no additional partitioning of the primary spend data on imports. The I-O model has allowed for spending leakages to imports in subsequent rounds of economic activity. It is possible that some reported expenditure in the Brisbane SD flows directly to imports, and that the direct stimulus is slightly over-estimated for this SD.

\subsection{Indirect and Final Consumption Effects}

The I-O modelling conducted for this project has estimated the indirect and consumption effects flowing from the two key direct impacts on the economy. One set of impacts is generated by business expenditure in each SD, while the other set of impacts is generated by employment expenditure in each area. These impacts have been modelled to identify the level of impacts on output, incomes, employment and industry value added for each SD (Table 6), incorporating both indirect and consumption effects. Total effects are summarised for each SD (Table 7). The I-O for each SD identified a proportion of outputs that occurred outside of the SD but still in Queensland, without identifying the distribution of those out-of-region impacts. Most of these out-of-region impacts are likely to accrue to Brisbane or other major metropolitan areas.

The results show that the resources industry has the highest overall impact on output and jobs in Brisbane, indicating that much of the stimulus flows through to south-east Queensland. However, significant job creation also occurs in the Mackay, Fitzroy, Northern and NorthWest SDs, with total resources sector driven employment accounting for up to $53 \%$ of jobs in the North-West region, $46 \%$ of jobs in the Mackay region, and $36 \%$ in the Fitzroy region. Employment multipliers are highest in the Brisbane SD, with more than 19 jobs created for each additional mining job.

\section{BENEFITS BY LOCAL GOVERNMENT AUTHORITIES}

Queensland resources sector expenditures, split across salary and supplier and voluntary community contribution expenditure, varied considerably across LGAs. The level of employment, and direct expenditure on employees, including direct employees and contractors, as well as expenditure on business supplies, is illustrated in the figures below. 
Table 4: Estimates of Economic Impact of the Resources Sector on the Queensland Economy Over Time

\begin{tabular}{|l|r|r|r|}
\hline & \multicolumn{2}{|c|}{$\begin{array}{c}\text { QDME (ACIL Tasman) (2007) } \\
\text { study - Mining and Minerals } \\
\text { Processing sectors only }\end{array}$} & $\begin{array}{c}\text { QRC - CQU } \\
\text { study - full } \\
\text { Resources } \\
\text { sector }\end{array}$ \\
\hline & $1999-00$ data & 2004-05 data & $2009-10$ data \\
\hline Direct Output (A $\$$ ) & 17,036 & 32,412 & 38,573 \\
\hline Direct Value Added at market prices (A $\$$ ) & 7,233 & 15,377 & 22,309 \\
\hline $\begin{array}{l}\text { Direct contribution to total factor income } \\
\text { (A\$ m) }\end{array}$ & 5,590 & 11,650 & 18,972 \\
\hline$\%$ Gross State Product (GSP) & $8.4 \%$ & $9.7 \%$ & $11.7 \%$ \\
\hline Direct Employment & 21,800 & $50,057 *$ & 38,093 \\
\hline Total employment effects & 93,235 & 216,041 & 292,094 \\
\hline Value of exports (A $\$$ m) & 12,290 & 21,809 & 26,647 \\
\hline$\%$ Total Exports & $57 \%$ & $62 \%$ & $62 \%$ \\
\hline Royalty payments (A\$ m) & 463 & 1,450 & 2,093 \\
\hline
\end{tabular}

* This estimate is likely to include contractors as well as direct employees.

Table 5: Direct Economic Impacts of the Resources Sector by SD

\begin{tabular}{|l|r|r|r|r|r|r|}
\hline & $\begin{array}{r}\text { Total } \\
\text { Employment }\end{array}$ & $\begin{array}{c}\text { Gross } \\
\text { Regional } \\
\text { Product }\end{array}$ & \multicolumn{4}{|c|}{ Resource sector impacts } \\
\hline & & & \multicolumn{1}{|c|}{$\begin{array}{c}\text { Residing } \\
\text { employees }\end{array}$} & $\begin{array}{c}\text { Salaries } \\
\text { spend }\end{array}$ & $\begin{array}{c}\text { Business } \\
\text { supplier \& } \\
\text { community } \\
\text { spend }\end{array}$ & $\begin{array}{c}\text { Total } \\
\text { Economic } \\
\text { stimulus }\end{array}$ \\
\hline Brisbane & $1,072,287$ & 107,793 & 6,940 & 903.8 & $9,479.0$ & $10,382.8$ \\
\hline Central West & 7,663 & 821 & 77 & 10.0 & 25.3 & 35.2 \\
\hline $\begin{array}{l}\text { Darling } \\
\text { Downs }\end{array}$ & 120,847 & 12,328 & 1,185 & 154.3 & 430.4 & 584.7 \\
\hline Far North & 132,552 & 13,173 & 1,485 & 193.4 & 114.3 & 307.7 \\
\hline Fitzroy & 111,223 & 15,714 & 9,627 & $1,253.7$ & $2,406.7$ & $3,660.4$ \\
\hline Gold Coast & 261,609 & 27,399 & 218 & 28.4 & 113.3 & 141.7 \\
\hline Mackay & 90,255 & 16,964 & 10,322 & $1,344.3$ & $2,678.8$ & $4,023.0$ \\
\hline North West & 18,759 & 5,288 & 3,979 & 518.2 & 927.8 & $1,446.0$ \\
\hline Northern & 125,777 & 12,218 & 2,659 & 346.3 & 654.7 & $1,001.0$ \\
\hline South West & 15,844 & 1,956 & 301 & 39.2 & 139.5 & 178.6 \\
\hline $\begin{array}{l}\text { Sunshine } \\
\text { Coast }\end{array}$ & 151,028 & 14,325 & 377 & 49.1 & 157.5 & 206.6 \\
\hline West Moreton & 44,328 & 3,513 & 183 & 23.9 & 16.1 & 40.0 \\
\hline $\begin{array}{l}\text { Wide Bay- } \\
\text { Burnett }\end{array}$ & 120,988 & 12,336 & 677 & 88.1 & 213.5 & 301.6 \\
\hline Total QLD & $2,273,160$ & 243,828 & 38,030 & $4,952.7$ & $17,356.7$ & $22,309.5$ \\
\hline
\end{tabular}


की
zo
$\vdots$
0
0

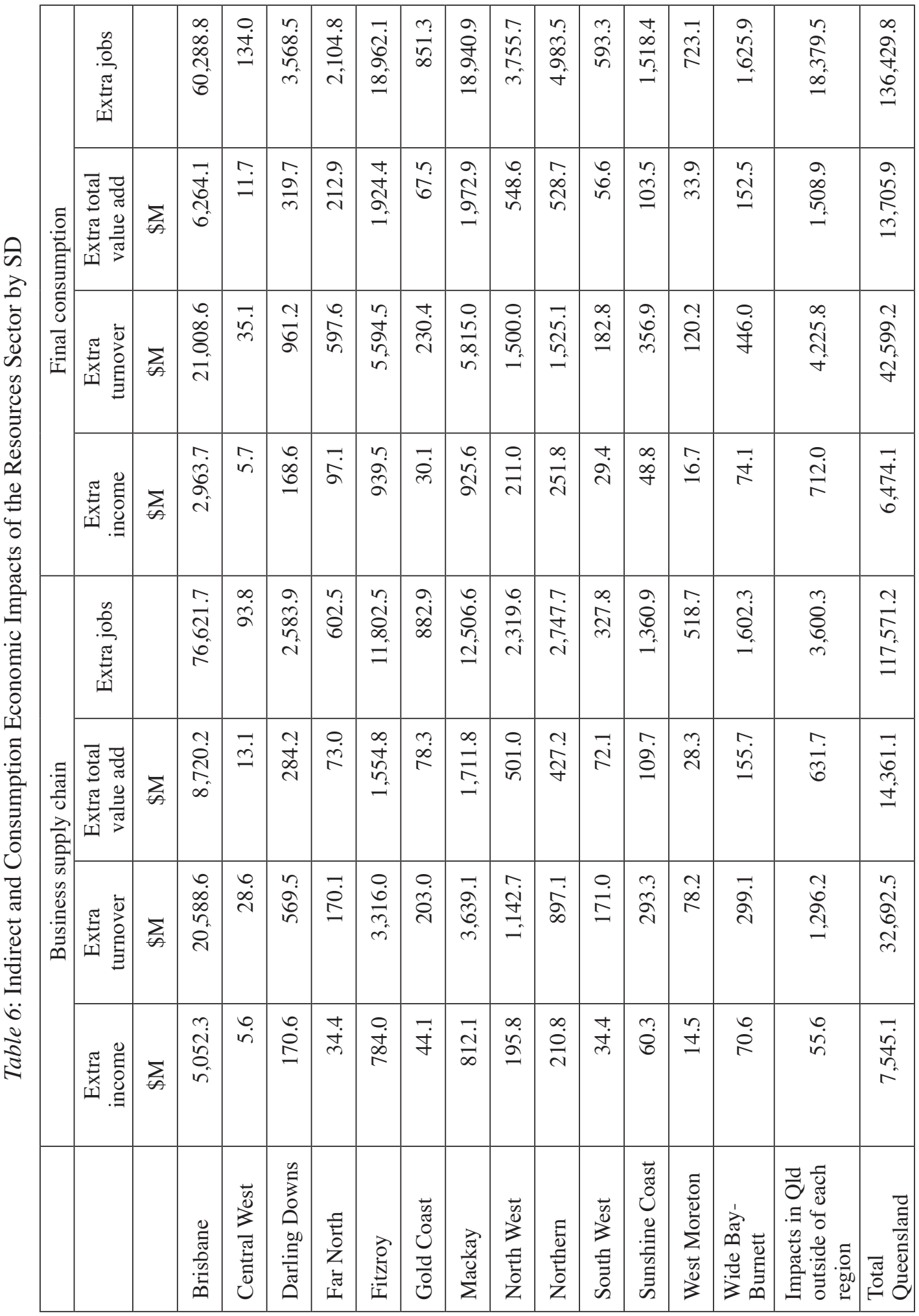


Table 7: Total Economic Impacts of the Resources Sector by SD

\begin{tabular}{|c|c|c|c|c|c|c|}
\hline & $\begin{array}{l}\text { Total output } \\
\text { (initial + } \\
\text { addition) }\end{array}$ & $\begin{array}{c}\text { Total } \\
\text { Income } \\
\text { (Initial + } \\
\text { addition) }\end{array}$ & $\begin{array}{c}\text { Addition } \\
\text { to GSP } \\
\text { (expenditure } \\
+ \text { Value Add) } \\
\end{array}$ & $\begin{array}{l}\text { Total jobs } \\
\text { (Initial + } \\
\text { addition) }\end{array}$ & $\begin{array}{l}\% \text { of } \\
\text { regional } \\
\text { workforce }\end{array}$ & $\begin{array}{l}\text { Additional } \\
\text { job } \\
\text { multiplier }\end{array}$ \\
\hline & $\$$ million & $\$$ million & \$ million & & & \\
\hline Brisbane & $41,597.3$ & $8,920.5$ & $25,366.23$ & $143,849.5$ & 13.4 & 19.7 \\
\hline Central West & 64.0 & 21.3 & 60.20 & 304.8 & 4.0 & 3.0 \\
\hline Darling Downs & $1,530.8$ & 493.6 & $1,188.78$ & $7,338.4$ & 6.1 & 5.2 \\
\hline Far North & 768.1 & 312.7 & 578.48 & $4,192.3$ & 3.2 & 1.8 \\
\hline Fitzroy & $8,910.5$ & $2,978.2$ & $7,140.43$ & $40,389.6$ & 36.3 & 3.2 \\
\hline Gold Coast & 433.4 & 102.7 & 287.56 & $1,952.2$ & 0.7 & 8.0 \\
\hline Mackay & $9,454.1$ & $3,083.0$ & $7,708.75$ & $41,769.5$ & 46.3 & 3.0 \\
\hline North West & $2,642.7$ & 925.4 & $2,496.19$ & $10,053.3$ & 53.6 & 1.5 \\
\hline Northern & $2,422.2$ & 809.2 & $1,957.20$ & $10,390.2$ & 8.3 & 2.9 \\
\hline South West & 353.7 & 103.0 & 307.37 & 1,221.1 & 7.7 & 3.0 \\
\hline Sunshine Coast & 650.2 & 158.2 & 419.81 & $3,256.3$ & 2.2 & 7.6 \\
\hline West Moreton & 198.3 & 55.1 & 102.16 & $1,425.8$ & 3.2 & 6.7 \\
\hline Wide Bay-Burnett & 745 & 232.9 & 609.80 & $3,904.2$ & 3.2 & 4.8 \\
\hline $\begin{array}{l}\text { Impacts in Qld } \\
\text { outside of each } \\
\text { region }\end{array}$ & $5,503.90$ & 776.30 & $2,153.15$ & $22,046.80$ & & \\
\hline Total Queensland & $113,846.6$ & $18,972.2$ & $50,376.1$ & 292,094 & & \\
\hline
\end{tabular}

Figure 3: Salary Payments in Queensland LGAs with Top Ten Expenditure Areas labelled

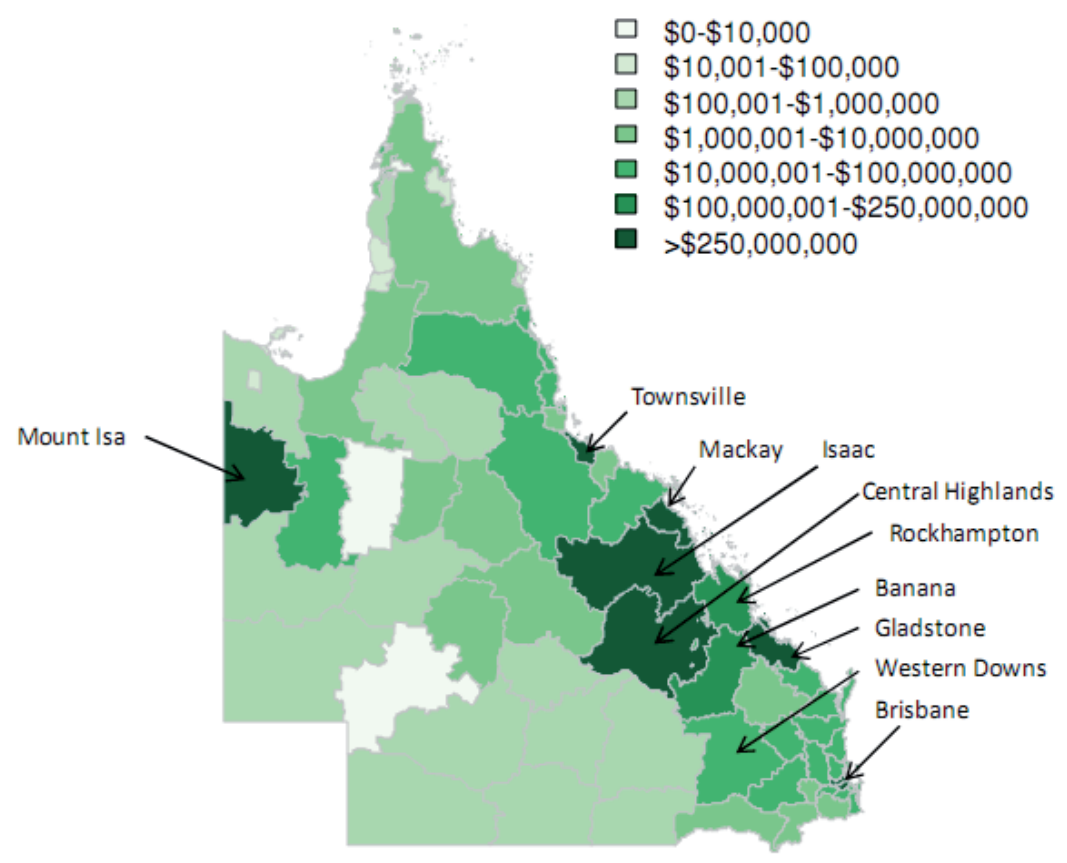


Salary expenditures were greatest in the Isaac Regional LGA followed by the Central Highlands Regional LGA, Brisbane City LGA, Mackay Regional LGA and Townsville City LGA. Comparison of Figure 3 (salaries) and Figure 4 (supplier expenditures) show that while almost all LGAs are receiving some impacts, there are differences in the concentration of expenditures in general (note there are different scales between figures).Comparing an ordering of expenditures obtained from ranking LGAs by salary and an ordering from a ranking by supplier expenditure, matches can only be found in only 4 cases (5\% of LGAs).

Figure 4 shows the distribution of supplier expenditures from resources companies across Queensland. The graphic shows that business expenditure tends to be more concentrated in some LGAs than salary expenditure. Of the LGAs listed, five are locations of major ports whilst another (Rockhampton Regional LGA) is a major regional population and industrial centre.

Figure 4: Supplier Expenditures in Queensland LGAs with Top Ten

Expenditure Areas Labelled

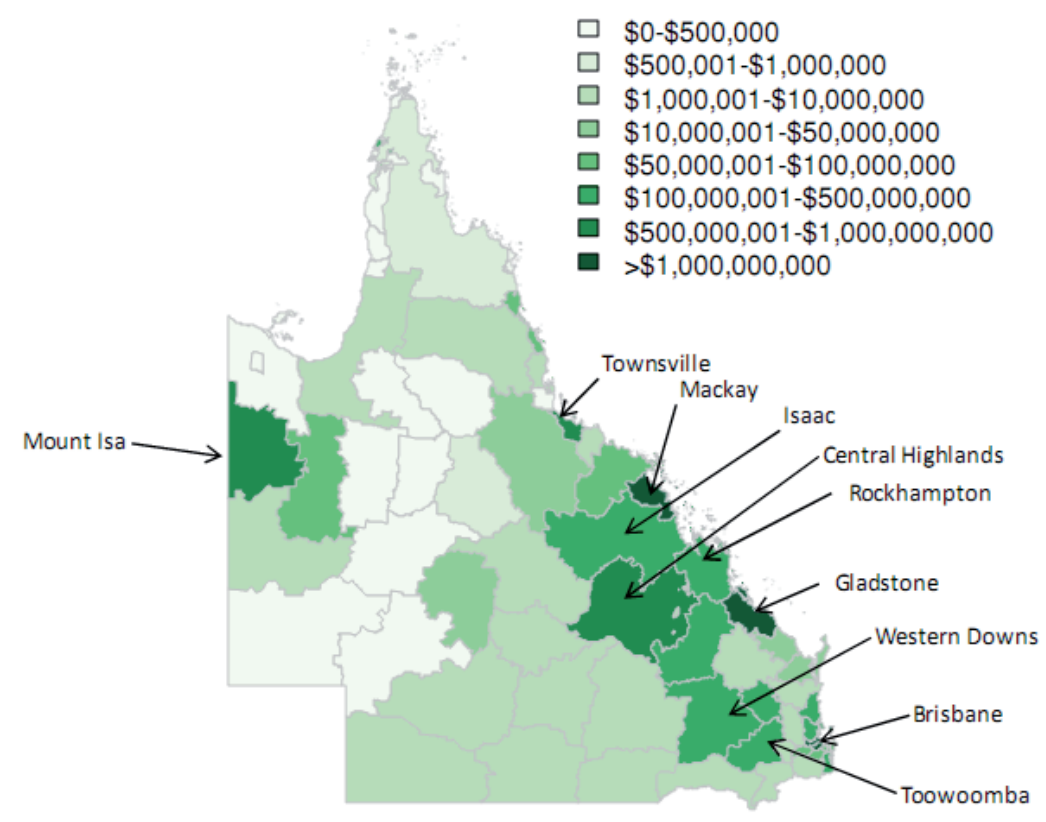

7.1 Indirect and Final Consumption Effects

The I-O modelling conducted for this project has estimated the indirect and consumption effects flowing from the two key direct impacts on the economy. One set of impacts is generated by business expenditure in each LGA, while the other set of impacts is generated by employment expenditure in each area. These impacts have been modelled to identify the level of impacts on output, incomes, employment and industry value added for each LGA (Figures 5 and 6 ). 
The I-O model for each SD identified a proportion of outputs that occurred outside of the SD but still in Queensland, without identifying the distribution of those out-of-region impacts. Most of these out-of-region impacts are likely to accrue to Brisbane or other major metropolitan areas.

Modelling consumption impacts is problematic for smaller shires with limited economic structures because only a subset of goods and services are available. Smaller and specialised mining LGAs tend to have larger expenditure leakages, typically to the nearest large regional centre. To incorporate this into the modelling, a further correction factor has been applied for LGAs, as shown in Table 8. The rates were further reduced for the mining-focused LGAs of Central Highlands (70\%), Isaac (40\%), Mount Isa (70\%) and Weipa (30\%) to account for the tendency of residents of those communities to travel to major centres for consumption spending.

Table 8: Rates of Adjustment for Local Consumption Expenditure by LGA Population Size

\begin{tabular}{|c|c|}
\hline $\begin{array}{c}\text { Population of } \\
\text { LGA }\end{array}$ & $\begin{array}{c}\text { Rate of consumption expenditure } \\
\text { in LGA }\end{array}$ \\
\hline $0-1,000$ & $30 \%$ \\
\hline $1,001-5,000$ & $50 \%$ \\
\hline $5,000-10,000$ & $60 \%$ \\
\hline $10,000-20,000$ & $70 \%$ \\
\hline $20,000-30,000$ & $80 \%$ \\
\hline$>30,000$ & $100 \%$ \\
\hline
\end{tabular}

Figure 5: Extra Value-Add in Business Supply Chain by LGA

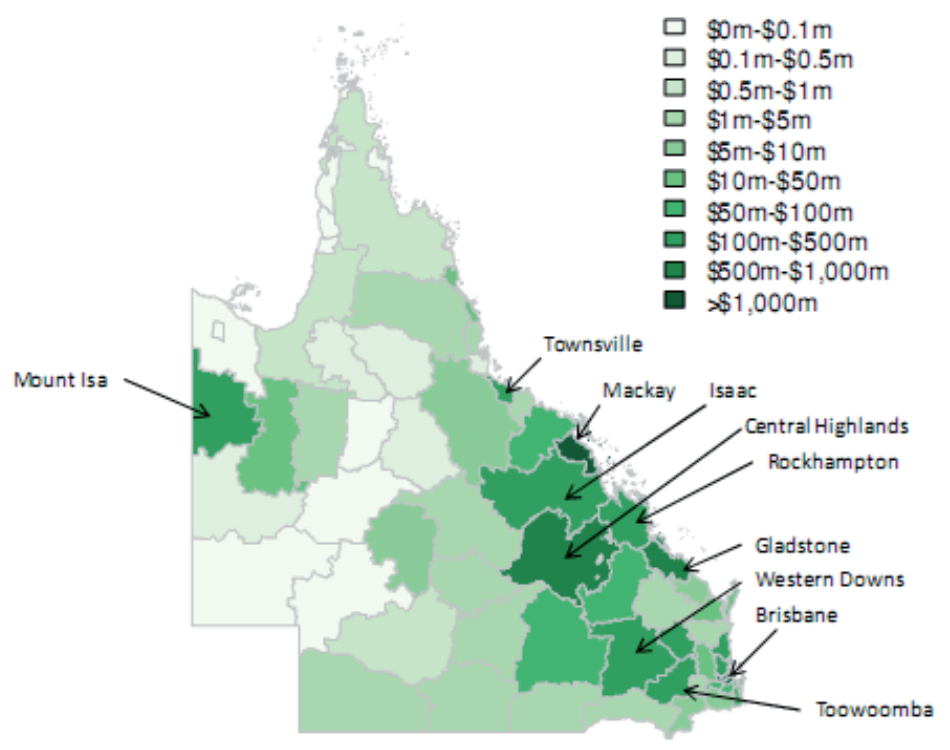


The results show that the resources industry has the highest overall impact on output and jobs in the Brisbane LGA, indicating that much of the stimulus flows through to south-east Queensland. There were substantial additions to the business supply chain in many LGAs, including Brisbane ( $\$ 8.4$ billion), Mackay ( $\$ 1.4$ billion), Gladstone ( $\$ 0.65$ billion), Mt Isa ( $\$ 0.69$ billion), and Townsville ( $\$ 0.42$ billion). The largest total additions to Gross Regional Product were made in the following LGAs: Brisbane (\$24.1 billion), Mackay ( $\$ 5.0$ billion), Gladstone ( $\$ 2.5$ billion), Mt Isa ( $\$ 2.2$ billion), Central Highlands ( $\$ 2.1$ billion), and Isaac (\$2.0 billion).

Figure 6: Total Addition to Gross Regional Product by LGA

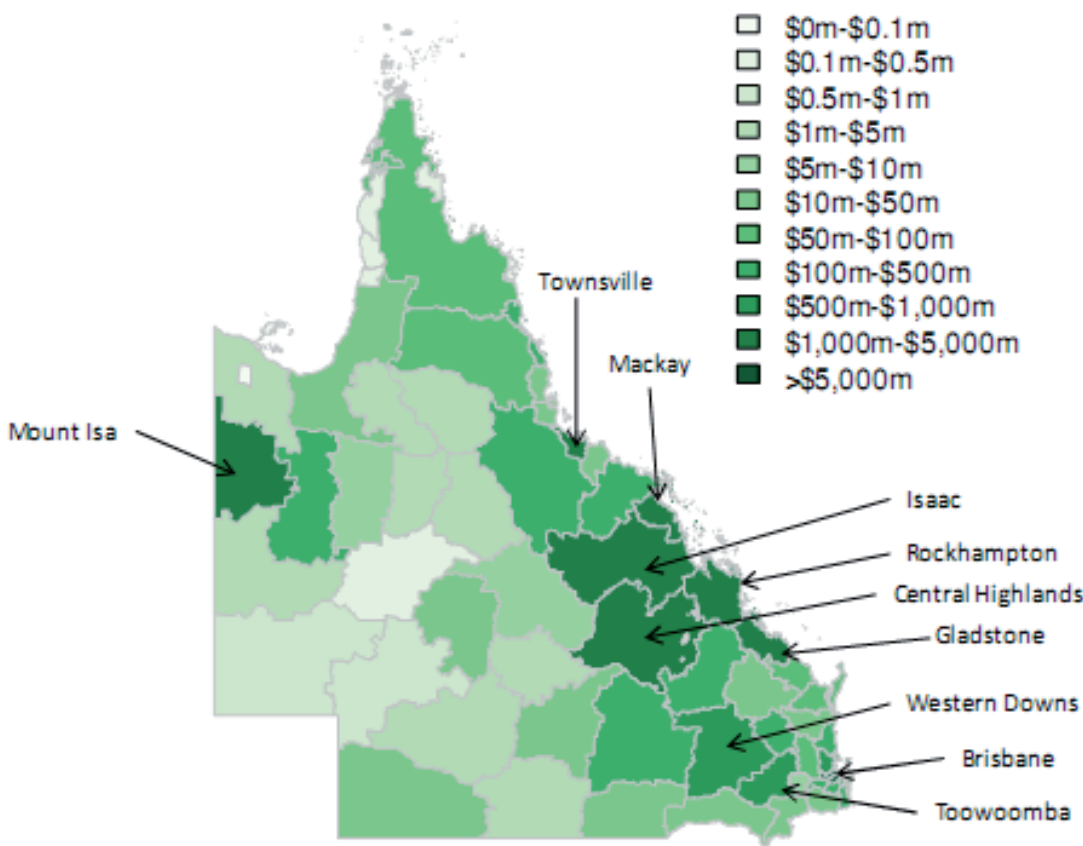

\section{CONCLUSIONS}

This paper contains the outcomes of two key pieces of analysis. The first is the collection of primary data through the QRC that identifies the direct economic stimulus of resources industries by local and regional areas in Queensland. The second is the conduct of I-O modelling that identifies the flow-on effects through the economy at a State, Statistical Division and Local Government Authority level.

The results of the analysis demonstrate that incomes and expenditures from the resources sectors are widely distributed across the state, and generate significant flow-on effects. It is notable that the industry makes a strong direct contribution in many of the more remote areas 
of Queensland, helping to underpin economic conditions in those regions. Expenditure from the resources industry has indirect impacts on the business environment in many areas, and generates substantial levels of production in south-east Queensland and central Queensland in particular.

A comparison to the previous estimates reported by the Queensland Department of Mines and Energy (2007) for only the mining and minerals processing sectors identifies that the resources sector has grown significantly within the Queensland economy. For example, the results of this study indicate that up to $\$ 18.97$ billion are being paid in direct and indirect salaries from the resources sector in 2009-10, compared to $\$ 5.09$ billion in 1999-00 and $\$ 11.12$ billion in 2004-05 (mining and minerals processing only). The results of this study demonstrate how those wages and salaries are being widely distributed across Queensland through direct, indirect and consumption effects.

\section{ACKNOWLEDGEMENTS}

This research has been supported by the Queensland Resources Council.

\section{REFERENCES}

Aroca, P. (2001). Impacts and development in local economies based on mining: the case of the Chilean II region, Resources Policy. 27: 119-134.

Bangsund, D.A. and F.L. Leistritz (2007). Economic Contribution of the Petroleum Industry to North Dakota, Agribusiness and Applied Economics Report No. 599, Department of Agribusiness and Applied Economics, North Dakota State University, Fargo, North Dakota 58105.

Fannin, J.M., D.W. Hughes, W.R. Keithly, W.O. Olatubi, and J. Guo (2008). Deepwater energy industry impacts on economic growth and public service provision in Lafourche Parish, Louisiana, SocioEconomic Planning Sciences. 42: 190-205.

Garton, P. (2008) The Resources Boom and the Two-speed Economy, Economic Roundup Issue 3, Australian Treasury, Canberra.

Jensen, R. C. and G. West (2002). Community Economic Analysis, Department of Primary Industries, QLD Government, Brisbane.

Leaming, G. (2010). The economic impact of the Arizona copper industry 2009. Report prepared for Western Economic Analysis Center.

Lim, G.C., C.L. Chua, E. Claus and S. Tsiaplias (2009). Review of the Australian economy 2008-09: Recessions, retrenchments and risks, The Australian Economic Record. 42: 1-11.

Local Government Association of Queensland (LGAQ) (2010). Supporting Queensland's Resource Regions, position paper developed by the Local Government Association of Queensland, Brisbane.

Loveridge, S. (2004). A typology and assessment of Multi-sector Regional Economic Impact Models, Regional Studies. 38: 305-317.

Queensland Government(Department of Mines andEnergy) (2007).Queensland Industries: The economic significance of mining and mineral processing to Queensland, Summary Report, Department of Mines and Energy, Brisbane.

Rolfe, J., R. Miles, S. Lockie, and G. Ivanova (2007). Lessons from the social and economic impacts of the mining boom in the Bowen Basin 2004 - 2006, Australasian Journal of Regional Studies. 13: 134-153.

Rolfe, J., R. Lawrence, D. Gregg, F. Morrish, and G. Ivanova (2010). Minerals and Energy Resources Sector in Queensland Economic Impact Study, report prepared for the Queensland Resources Council, The Eidos Institute, Brisbane. 
Rubin, B. and B. Solomon (1983). Economic and fiscal impact analysis of energy development projects: Coal liquefaction in the Illinois Basin, Socio-Economic Planning Sciences. 17: 11-20.

Stillwell, L., R. Minnitt, T. Monson, and G. Kuhn (2000). An input-output analysis of the impact of mining on the South African economy, Resources Policy. 26: 17-30.

Zheng, C., L. DiMilia, J. Rolfe, and P. Bretherton (2007). Strategic People Management of Coal Mining Firms in Central Queensland, Management Research News. 30: 302-311. 